\title{
Anti- CCP Antibody and Rheumatoid Factor Positivity in a Case of Tuberculosis Arthritis
}

\author{
Tüberküloz Artritli Bir Olguda Anti- COP ve Romatoid Faktör Pozitiflig̈i
}

\author{
Murat Karkucak , Erhan Çapkın, Ömer Faruk Barçak, Haşim Çakırbay, Mehmet Tosun, Ferhat Gökmen \\ Karadeniz Teknik Üniversitesi, Fiziksel Tıp ve Rehabilitasyon Anabilim Dalı, Trabzon, Turkey
}

\section{Abstract}

Tuberculosis (TB) can affect vertebras and joints bearing weight. It can resemble clinic signs, radiological and laboratory findings of rheumatoid arthritis (RA) involving peripheral joints. TB can make rheumatoid factor (RF) and anti-cyclic citrullinated peptide (CCP) positive, which are used in the diagnosis of RA arthritis. Therefore, this causes some difficulties in clinic diagnosis. Additionally, the diagnostic problems in TB arthritis can be more complicated. We aimed to attract attention to this situation by presenting a case of TB arthritis in which anti-CCP and RF are positive. (Turk J Rheumatol 2010; 25: 95-8)

Key words: Tuberculosis arthritis, rheumatoid arthritis, rheumatoid factor, anti-CCP

Received: 20.05 .2009

Accepted: 06.07.2009
Özet

Tüberküloz (TB) iskelet sisteminde vertebraları ve yük binen eklemleri etkiliyebilir. Periferik eklem tutulumunda romatoid artrit (RA)'i taklit eden klinik, laboratuar ve radyolojik bulgular olușturabilir. TB, günümüzde RA'nın erken tanısında kullanılmakta olan romatoid faktör(RF) ve anti-cyclic citrullinated peptide (CCP) pozitifliği olușturabilir. Bu durum klinik tanıda zorluklara yol açar. İlave olarak TB artritdeki tanısal zorluklar bu durumu daha da karmașık hale getirir. Biz burada Anti-CCP ve RF pozitif olan TB artritli bir vaka sunarak bu duruma dikkat çekmeyi amaçladık.(Turk J Rheumatol 2010; 25: 95-8)

Anahtar sözcükler: Tüberküloz artriti, romatoid artrit, romatoid faktör, anti CCP

Alındığı Tarih: 20.05.2009 Kabul Tarihi: 06.07.2009

\section{Introduction}

The primary organ affected by Mycobacterium tuberculosis is the lungs; skeletal system involvement is rare. Although the vertebrae are the major site of involvement in the skeletal system, peripheral joint involvement can also occur. The most common side of involvement in joint tuberculosis (TB) are the hip and knee joint $(1,2)$.

Rheumatoid arthritis (RA) is characterized by chronic inflammation in the synovial membrane of the joints. Recently, specific auto-antibodies against epidermal filagrin have been described in $40 \%-60 \%$ of patients with RA. Anti-cyclic citrullinated peptide (anti-CCP) is one of these antibodies. Anti-CCP antibodies have been reported to be a novel and more specific diagnostic marker than rheumatoid factor (RF) in the diagnosis of RA. Antibodies that are formed against CCP primarily belong to the immunoglobulin $\mathrm{G}$ class and are $97 \%$ specific for RA. AntiCCP antibodies may be detected in $79 \%$ of patients in the early stages of the disease $(3,4)$. Specificity rises to $98 \%$ when both RF and anti-CCP are positive. In a recent study, anti-CCP antibody positivity has been reported in $32 \%$ of patients with active pulmonary TB (5). This may lead to diagnostic and therapeutic errors in patients with monoand oligo-arthritis, as well as in patients with reactive arthritis secondary to mycobacteria. TB arthritis may be confused with RA due to its radiologic features, including periarticular osteopenia and marginal erosions (6).

A chronic arthritis patient with positive RF and antiCCP is presented in this report to highlight other clinical conditions which may lead to RF and anti-CCP positivity in light of the current medical literature.

\section{Case report}

A 72-year-old male patient was admitted to our outpatient clinic with pain, swelling, and limited range of motion of the left knee, and difficulty in walking. His knee complaints had begun suddenly 1 year ago and he also had intermittent right hip joint pain. He had 1 hour

Address for Correspondence: Dr. Erhan Çapkın, Karadeniz Teknik Üniversites, Fiziksel Tıp ve Rehabilitasyon Anabilim Dalı, Trabzon, Turkey Phone: +9046237754 26E- mail: drcapkin@yahoo.com

doi: 10.5152/tjr.2010.10 
of morning stiffness and his symptoms were slightly reduced by activity. He did not have any episodes of infections prior to symptom onset. He did not report fever, weight loss or sweating, and his rheumatologic history was uneventful other than his joint complaints. Despite the use of several non-steroidal anti-inflammatory drugs, there was no improvement in his knee pain, swelling, and range of motion. The anamnesis of the patient was unremarkable except he was treated for pulmonary TB 50 years ago and underwent surgery on his right hip due to trochanteric bursitis 3 years ago. On physical examination swelling and limited range of motion was observed in left knee. After activity, pain and increased temperature was also noted. His right hip joint motion was mildly painful without any limitation. Laboratory investigations revealed a white blood cell count of 6200/uL (normal range; 4800$10800 / \mathrm{uL}$ ), hemoglobulin level of $12.8 \mathrm{mg} / \mathrm{dL}$ (normal range; $12-17 \mathrm{mg} / \mathrm{dL}$ ), platelet count of $630.000 / \mathrm{uL}$, erythrocyte sedimentation rate of $59 \mathrm{~mm} / \mathrm{h}$ (normal range; $0-20 \mathrm{~mm} / \mathrm{h}$ ), blood glucose level of $110 \mathrm{mg} / \mathrm{dL}$ (normal range; $70-110 \mathrm{mg} / \mathrm{dL}$ ), a C-reactive protein level of 8.99 $\mathrm{mg} / \mathrm{dL}$ (normal value; $<0.3 \mathrm{mg} / \mathrm{dL}$ ), RF level of $63.70 \mathrm{IU} / \mathrm{mL}$ (normal value; $<19 \mathrm{IU} / \mathrm{mL}$ ), and anti-CCP antibody as 21.8 $\mathrm{U} / \mathrm{mL}$ (normal value; 0-5 U/mL). The synovial fluid examination revealed a white blood cell count of 16.200/uL and a blood glucose level of $12 \mathrm{mg} / \mathrm{dL}$. Marginal erosions were noted on the radiograph of the left knee (Figure 1). The anteroposterior pelvic radiograph revealed a region of ossification lateral to the right hip joint corresponding to the trochanteric bursa region. Magnetic resonance imaging (MRI) of the left knee revealed extensive hyperintense synovial thickening and erosive changes within the

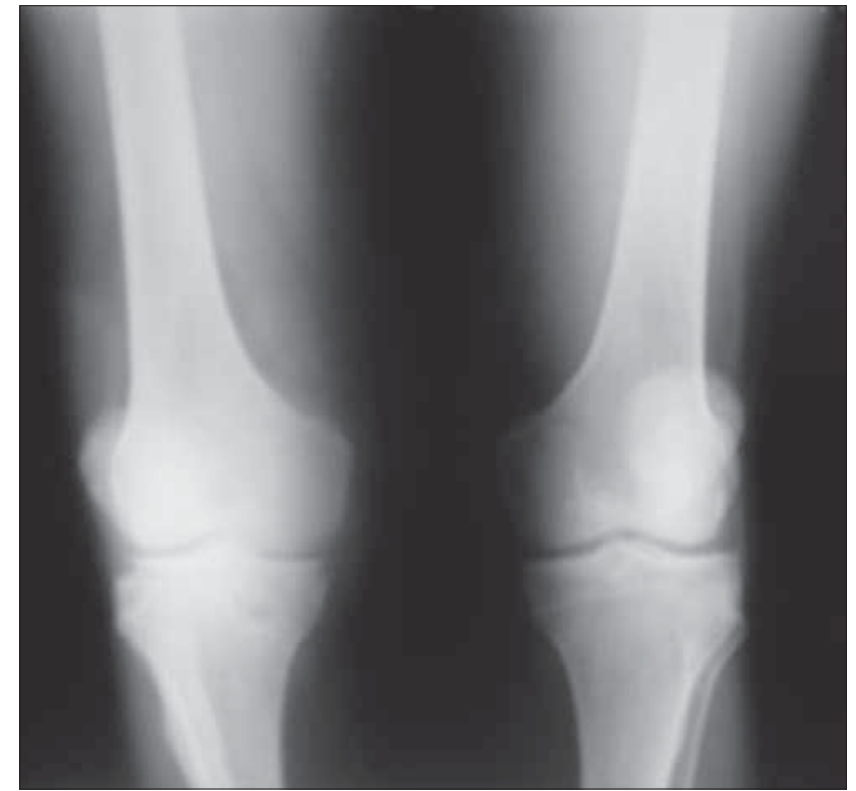

Figure 1. Anteroposterior radiograph of both knees (marginal erosions are noted in the left knee) joint cavity, including all knee compartments and the suprapatellar bursa on T2-weighted images (Figures 2, 3). On contrast-enhanced MRI evaluation, fields of necrosis associated with infection showing peripheral enhancement were observed. Bone and joint pathologies defined in these investigations were compatible with infection. The differential diagnosis included arthritis, osteomyelitis, and especially TB, thus the Departments of Infectious Diseases, Chest Diseases, and Orthopedics were consulted. The Department of Infectious Diseases recommended that two consecutive joint aspiration samples should be screened for acid-resistant bacilli (ARB). Indeed, ARB were detected in both joint aspiration fluid samples. On lung tomography, as recommended by the Department of Chest Diseases, revealed fibrotic scars in the bilateral upper lobes, which were thought to be secondary to previous infection. Arthroscopic debridement was performed by the Department of Orthopedics and the biopsy result was compatible with a granulomatous inflammatory reaction. The patient was diagnosed with TB arthritis and treated accordingly. Clinical and laboratory improvement was noted on follow-up.

\section{Discussion}

Tuberculosis is a significant health problem in developing countries. Several arthropathic forms, including TB arthritis and reactive arthritis, can be seen in patients with TB (7). TB arthritis commonly occurs in peripheral weightbearing joints. However, there have been several reports of small peripheral joint involvement in TB as well (8). This

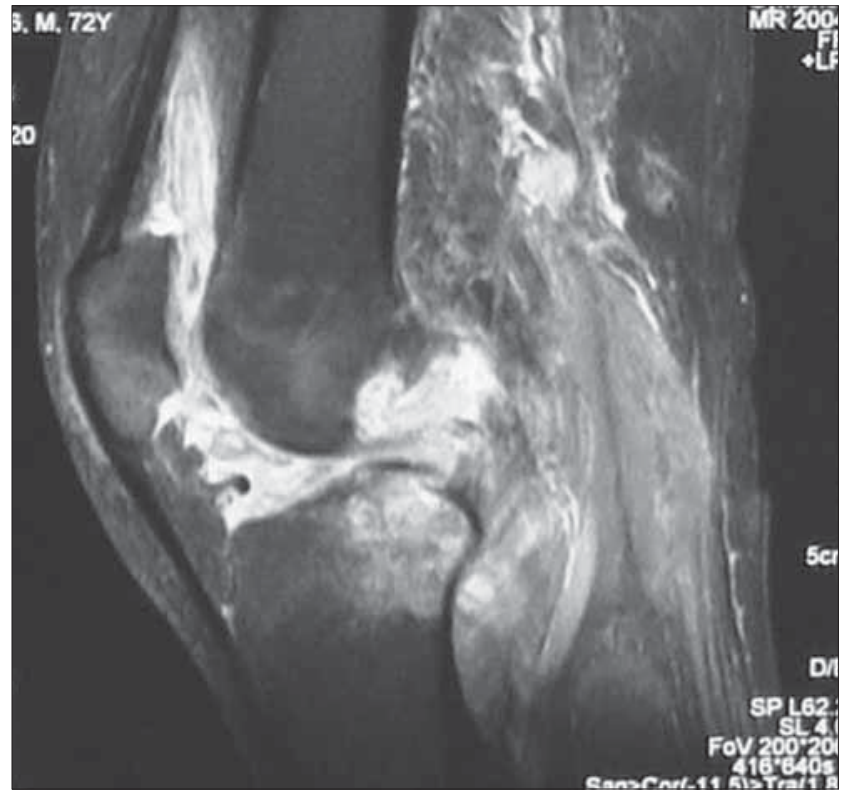

Figure 2. T2-weighted sagittal magnetic resonance image of the left knee 


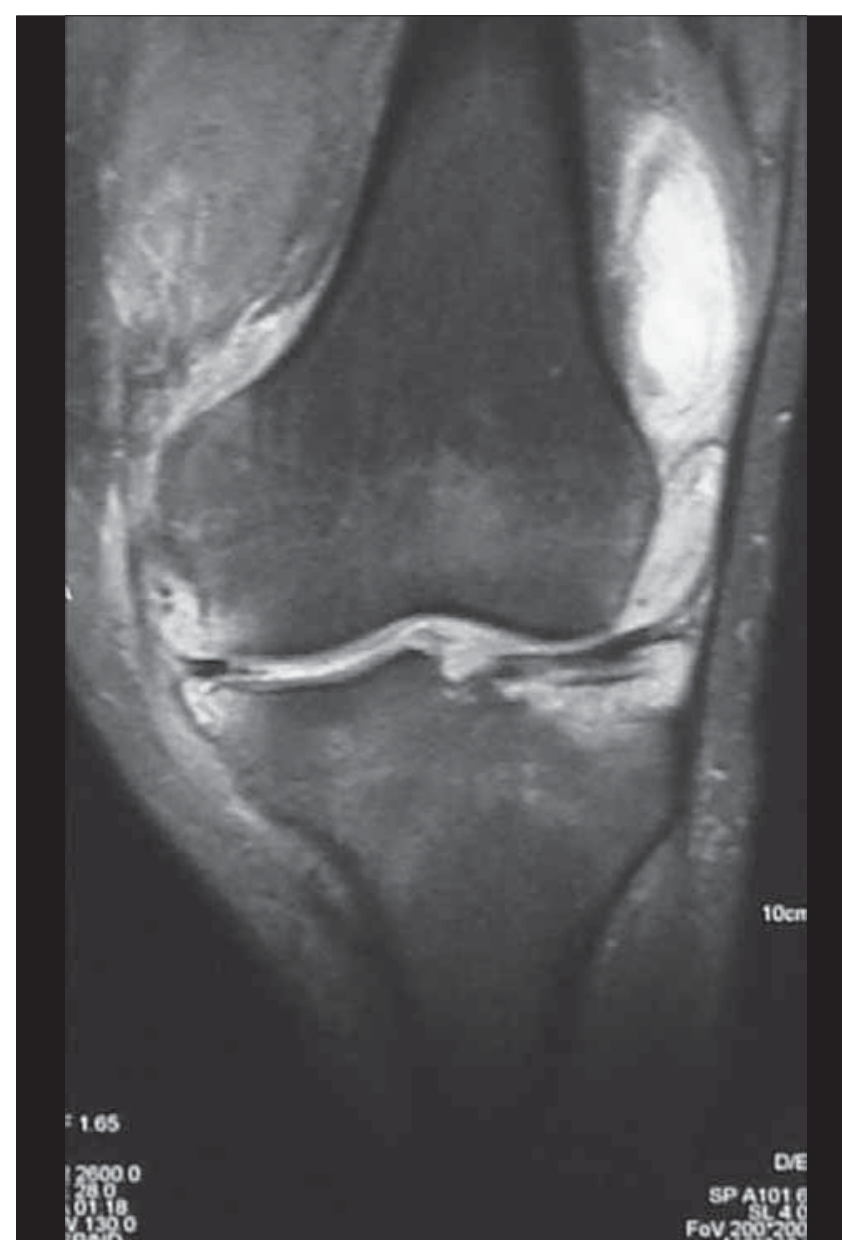

Figure 3. T2-weighted coronal magnetic resonance image of the left knee

may cause several diagnostic errors and clinical misunderstanding in the diagnostic and therapeutic work-up of early arthritis. In particular, mono- and oligo-arthritis caused by infections due to Mycobacterium spp. may resemble the synovitis observed in early RA (9). Infection by Mycobacterium spp. may also lead to RF positivity. Anti-CCP antibody positivity is currently a significant diagnostic tool for the early diagnosis of RA. Anti-CCP antibodies have been shown to have a specificity of $94.9 \%$ and a positive predictive value of $87.8 \%$ in the early diagnosis of RA. When both anti-CCP antibodies and RF are positive, the specificity rises to $96.9 \%$ and the positive predictive value is $90.9 \%$ (10). Anti-CCP antibodies and RF together seem to be a better marker for diagnosis and prognostic indicator.

In a recent study, the prevalence of anti-CCP antibodies was shown to be $37 \%$ in Japanese patients with active pulmonary TB (11). Elkayam et al. (5) compared anti-CCP antibody positivity and Immunoglobulin M (IgM) RF status in 47 patients with active pulmonary TB infection and 39 healthy controls. Anti-CCP titers were above normal in $32 \%$ of the patients with active TB infection, while the rate was only
$2.6 \%$ in controls. Also, IgM RF positivity rate was $62 \%$ in the TB group and $2.6 \%$ in the control group (5).

Kakumanu et al. (11) reported that anti-unmodified arginine-containing peptide (anti-CAP) levels were higher in patients with active TB infections compared to RA patients. While the anti-CAP/anti-CCP ratio was $>2$ in $94 \%$ of patients with RA, the same ratio was observed in only $22 \%$ of patients with TB. Thus, it was concluded that the anti-CCP/anti-CAP ratio could be used for differentiating TB arthritis from RA (11).

In contrast, Mori et al. (12) reported that anti-CCP antibodies were positive in 6 of 89 patients with active pulmonary TB $(6.7 \%)$ and $0.4 \%$ in the control group $(n=267)$. Although anti-CCP levels were higher compared to healthy controls, it was suggested that anti-CCP levels could be used in the early diagnosis of RA in patients with active TB. It was also stated that anti-CCP might become positive years before RA manifestations and these patients might develop RA at a later time period (12).

With the exception of hepatitis C virus (HCV) infection, anti-CCP antibody positivity in other infectious diseases has not been studied. Although RF is positive in $\mathrm{HCV}$ infections, anti-CCP antibodies are negative. AntiCCP appears to be a useful tool for the differentiation between HCV-associated arthritis and RA. It should be noted, however, that anti-CCP antibodies can also be positive, although at low titers, in rheumatic diseases other then RA, and in healthy individuals $(13,14)$.

Moreover, exacerbation of TB infection can occur in patients with RA both during the disease course and also due to immunosuppressive medications used for its treatment. An increase in inflammatory markers may be misinterpreted as activation of RA and lead to alterations in disease-modifying drug choices, and even initiation of treatment by biological agents (11).

Our patient was noted to have monoarthritis on initial physical examination and laboratory assessment with increased inflammatory markers. He was diagnosed with TB arthritis following synovial fluid analysis, cultures, and biopsy, and appropriate treatment was initiated. However, diagnosis may not be as straightforward in many cases as in this case due to the challenges in identifying TB. Owing to high sensitivity and specificity for RA, the presence of RF and anti-CCP antibodies might lead to errors in the differential diagnosis. Further studies are needed to identify other conditions causing anti-CCP antibody positivity. Chronic infectious etiologies should always be kept in mind during the diagnostic work-up of patients presenting with arthritis and the anamnesis, physical examination, and laboratory findings of patient should be evaluated carefully.

\section{Conflict of Interest}

No conflict of interest is declared by authors. 


\section{References}

1. Hoffman EB, Campbell JA, Lee AS. Tuberculosis of the hip and knee in children. S Afr Bone Joint Surg 1995; 1: 248.

2. Silva JF. A review of patients with skeletal tuberculosis treated at the University Hospital, Kuala Lumpur. Int Orthop 1980; 4: 79-81.

3. Van Boekel MA, Vossenaar ER, van den Hoogen FH, van Venroo WJ.Autoantibody systems in rheumatoid arthritis: specificity, sensitivity and diagnostic value. Arthritis Res 2002; 4: 87-93.

4. Schellekens GA, Visser $H$, de Jong BAW, van den Hoogen FH, Hazes JM, Breedeveld FC, et al. The diagnostic properties of rheumatoid arthritis antibodies recognizing anti-cyclic citrullinated peptide. Arthritis Rheum 2000; 43: 155-63.

5. Elkayam O, Segal R, Lidgi M, Caspi D. Positive anti-cyclic citrullinated proteins and rheumatoid factor during active lung tuberculosis. Ann Rheum Dis 2006; 65: 1110-2.

6. Hugosson C, Nyman RS, Brismar J, Larsson SG, Lindahl S, Lundstedt C. Imaging of tuberculosis. Peripheral osteoarticular and soft tissue tuberculosis. Acta Radiol 1996; 37: 512-16.

7. Leonard $M$. The ever-expanding association between rheumatologic diseases and tuberculosis. Am J Med 2006; 119: 470-7.

8. Garrido G, Gomez-Reino JJ, Fernandez-Dapica P, Palenque E, Prieto $S$. A review of peripheral tuberculous arthritis. Semin Arthritis Rheum 1988; 18: 142-9.

9. Choi ST, Park MC, Lee SW, Park YB, Hahn SB, Lee SK. Hand involvement of Mycobacterium tuberculosis infection mimicking rheumatoid arthritis [letter]. Clin Exp Rheumatol 2006; 24: 347

10. Yamane $T$, Hashiramoto A, Tanaka $Y$, Tsumiyama $K$, Miura $Y$, Shiozawa $\mathrm{K}$ et al .Easy and accurate diagnosis of rheumatoid arthritis using anti-cyclic citrullinated peptide 2 antibody, swollen joint count, and C-reactive protein/rheumatoid factor. J Rheumatol 2008; 35: 414-20

11. Kakumanu P, Yamagata H, Sobel ES, Reeves WH, Chan EK, Satoh M Patients with pulmonary tuberculosis are frequently positive for anti-cyclic citrullinated peptide antibodies, but their sera also react with unmodified arginine-containing peptide. Arthritis Rheum 2008 Jun; 58: 1576-81

12. Mori $S$, Naito $H$, Ohtani $S$, Yamanaka $T$, Sugimoto $M$. Diagnostic utility of anti-cyclic citrullinated peptide antibodies for rheumatoid arthritis in patients with active lung tuberculosis. Clin Rheumatol 2008; 28: 277-83.

13. Wener MH, Hutchinson K, Morishima C, Gretch DR. Absence of antibodies to cyclic citrullinated peptide in sera of patients with hepatitis $C$ infection and cryoglobulinemia. Arthritis Rheum 2004; 50: 2305-8.

14. Bombardieri M, Alessandri C, Labbadia G, lannuccelli C, Carlucci F, Riccieri V, et al. Role of anti-cyclic citrullinated peptide antibodies in discriminating patients with rheumatoid arthritis from patients with chronic hepatitis $C$ infection-associated polyarticular involvement. Arthritis Res Ther 2004; 6: 137-41. 